\title{
On phase trajectory of dynamic system "directionally crystallized binary melt"
}

\author{
V.M.Kanishchev, V.P.Semynozhenko \\ Institute for Single Crystals, STC "Institute for Single Crystals", National \\ Academy of Sciences of Ukraine, 60 Lenin Ave., 61001 Kharkiv, Ukraine
}

Received March 25, 2014

The origin of return and self-crossing points on the parametrically specified curves of crystallization rate vs. impurities concentration at the interface during pulling a crystal from a binary melt at constant rate in the initial transitional stage has been explained.

\footnotetext{
Рассмотрены причины появления особенностей на параметрически заданных кривых зависимости скорости кристаллизации от концентрации примеси на межфазной границе при вытягивании кристалла из бинарного расплава с постоянной скоростью в начальном переходном процессе.

Про фазову траекторію динамічної системи "бінарний розплав, що крисралізується спрямовано". В.М.Каніщев, В.П.Семиноженко

Розглянуто причини виникнення особливостей на параметрично заданих кривих залежності швидкості кристалізації від концентрації домішки на міжфазній границі при витягуванні кристала з бінарного розплаву з постійною швидкістю у початковому перехідному процесі.
}

The representation of dynamic system phase trajectory [1] used in [2] allowed the author to explain the cause of the solid-melt interface oscillations during pulling a crystal from a binary melt at constant rate in the initial transitional stage. This representation also allowed a better graphical visualization of the results and a thorough investigation of the influence of crystal growing conditions on the interface's behavior in the transitional stage. One could see that the graphs had return and self-crossing points. The aim of this article is to shed light on these points.

After determining the impurity concentration in the melt against coordinate and time $C(x, t)$, where $x$ is found from the interface towards the melt [2], it is possible to determine the travel velocity of the flat solid-melt interface $V(t)$ in the transitional stage. In dimensionless variables, the problem of determining $C(x, t)$ has two input parameters: $k$ and $B$ - impurity distribution and concentration overcooling coefficients, respectively. This problem is nonlinear but

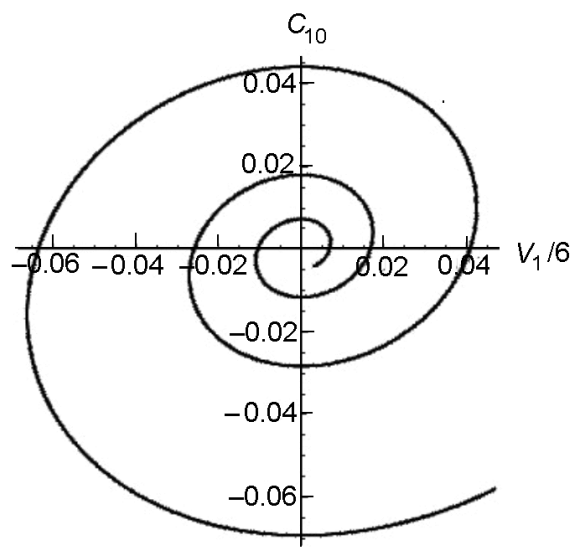

Fig. 1. Solid-melt interface impurity concentration $C_{10}$ vs. crystallization rate $V_{1}$, given in parametrical form at $k=0.5$ and $B=0.01$. 


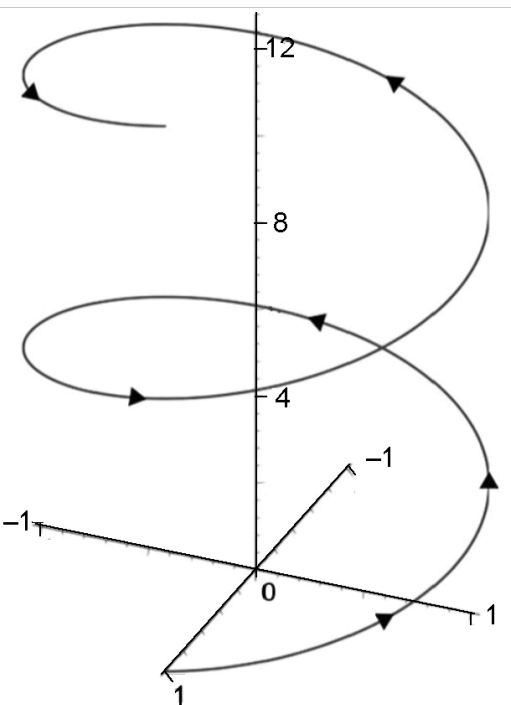

Fig. 2. Helix line: $x=\cos t, y=\sin t, z=t$.

at a greater time scale, it can be linearized, by assuming that

$$
C(x, t)=e^{-x}+C_{1}(x, t) .
$$

where $e^{-x}$ - impurity distribution in a stationary crystallization mode; $\left|C_{1}(x, t)\right|<<e^{-x}$.

The linearized problem takes the following form:

$$
\begin{gathered}
C_{1 x x}(x, t)+C_{1 x}(x, t)-e^{-x} V_{1}(\mathrm{t})= \\
=C_{1 t}(x, t),
\end{gathered}
$$
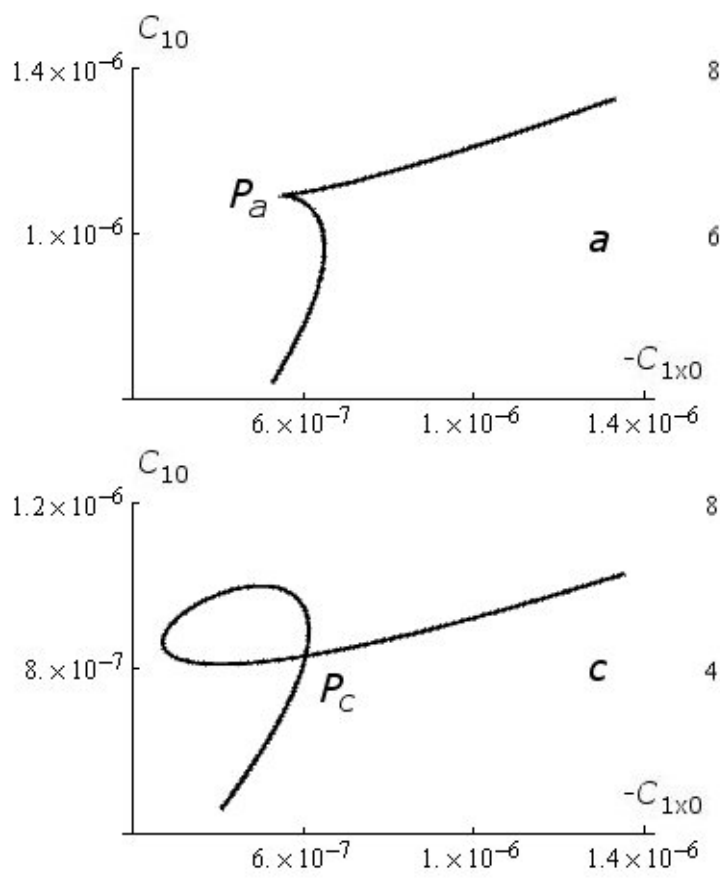

Fig. 3. Phase trajectory projection on planes $C_{1 \times 0}, C_{10}(a, c)$ and $C_{1 \times 1}, C_{11}(b, d)$ for $k=0.5$ and parameter values $B=0.5665(a, b), 0.563(c, d)$. Points of the curves correspond to the following time $t$ (arb. unit): $t=31.96\left(P_{a}\right.$ and $\left.P_{b}\right), 29.9$ and $36.2\left(P_{c}\right), 29.9\left(P_{d 1}\right), 36.2\left(P_{d 2}\right)$.

$$
\begin{gathered}
C_{1 x}(0, t)+(1-k) \mathrm{C}_{1}(0, t)+V_{1}(t)=0,(3) \\
V_{1}(t)=-C_{1 t}(0, t) / B \\
C_{1}(\infty, t)=0, C_{1}(x, 0)=-e^{-x}
\end{gathered}
$$

and can be comparatively easy solved by Laplace transform method. Here the indices $x$ and $t$ are coordinate and time partial derivatives of the concentration, respectively.

Having solved (2)-(5), it is quite easy to plot curves given in parametric form $C_{10}\left(-C_{1 \times 0}\right)$ or $C_{10}\left(V_{1}\right)$, where $C_{10}=C_{1}(0, t)$ and $C_{1 \times 0}=$ $\mathrm{C}_{1 x}(0, t)$. They clearly demonstrate, for example in Fig. 1 that the crystallization front of binary melt acts like a decaying harmonic oscillator. In [2] these parametric curves are called phase trajectories, though they are just several plane projections of infinitely dimensional line [3]. This error can lead to a following misunderstanding.

It is known [4] that a cycloid can be represented as a two-dimensional projection of a three-dimensional helical line (Fig.2). According to the angle between the helix line axes and the projection plane one can obtain a curve either with return points (general cycloid) or with self-crossing points (extended cycloid). It is worth noting that the curve self-crossing shown in Fig. 2 is
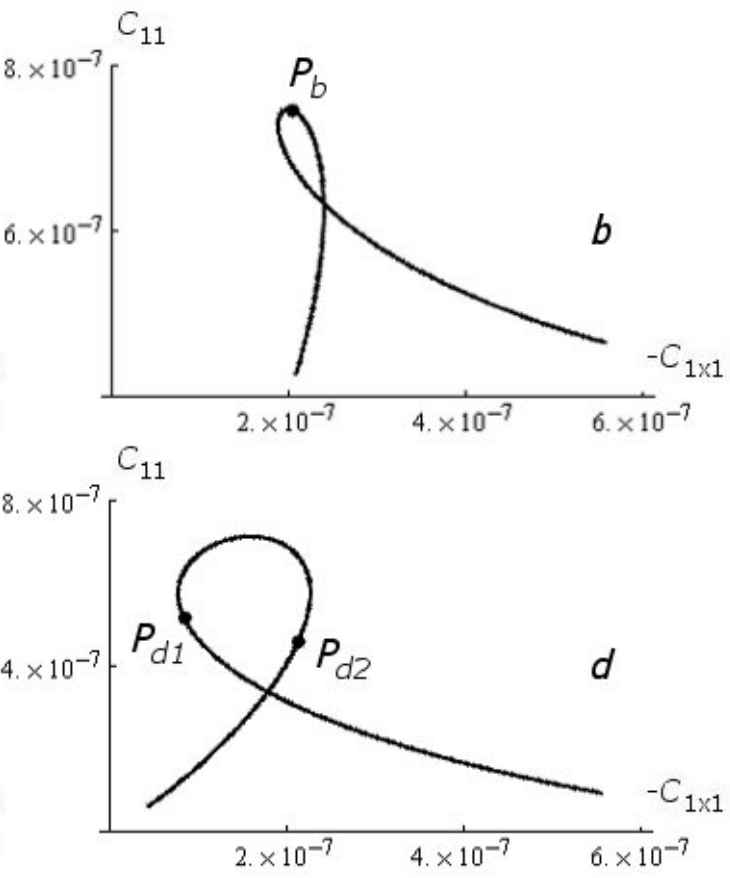
caused by the angle of ascent of helix line being smaller than the angle of plane of projected rays used in axonometry. It is obvious that the projection of the helix line does not illustrate the true arrangement of the helix line.

Fig. 3a and 3c show $C_{10}\left(-C_{1 \times 0}\right)$ dependence diagrams for two values of $B$ parameter and Fig. $3 \mathrm{~b}$ and $3 \mathrm{~d}$ show $C_{11}\left(-C_{1 \times 1}\right)$ dependence diagrams, where $C_{11}=C_{1}(1, t)$ and $C_{1 \times 1}=C_{1 x}(1, t)$. The curves in Fig. 3a и $3 \mathrm{~b}$ are just different projections of the same phase trajectory. One can see that the return point $P_{a}$ on a projection corresponds to $P_{b}$ point on $b$ projection. Note that they are just two projections out of their endless number. Fig. 3c and 3d demonstrate another typical case when the self-crossing point $P_{c}$ on $c$ projection corresponds to $P_{d 1}$ and $P_{d 2}$ points on $d$ projection. It turns out that the self-crossing point on $C_{10}\left(-\mathrm{C}_{1 \times 0}\right)$ curve corresponds to two different states of the system, which can be clearly seen by comparing impurity distributions at the mo- ment when $\left(C_{11},-C_{1 \times 1}\right)$ possess the same values.

Thus, the return and self-crossing points on $C_{10}\left(-\mathrm{C}_{1 \times 0}\right)$ or $C_{10}\left(V_{1}\right)$ curve can be mistakenly taken for the return and self-crossing points of the phase trajectory of the dynamic system "directionally crystallized binary melt".

The authors expresses their thanks to I.D. Tchueshov - a corresponding member of NAS of Ukraine for his invaluable suggestions and explanations.

\section{Reference}

1. A.A.Andronov, A.A.Vitt, S.E.Khaikin, Theory of oscillations. Fizmatgiz, Moscow (1959) [in Russian].

2. V.M. Kanishchev, Zh. Exper. i Teor. Fiz., 144, 1165 (2013).

3. I.D.Tchueshov. Introduction to the Theory of Infinite-dimensional Dissipative Systems, Acta, Kharkiv (1999) [in Russian].

4. http://matemonline.com/2011/06/cikloidy/ 